\title{
Truth And Control In Being And Language
}

\author{
J. KRUMMEL \\ New School for Social Research
}

Despite Heidegger's influence on Foucault, their vast differences both in content and purpose should not be denied. However, in this paper, I would like to explore the similarities they may hold-especially in their notions of language in its expression of "being". "Being" for Heidegger is the process of existence itself, the temporality of that which exists as it undergoes different transient formations- this process constituting its actuality as the movement of "presencing" into "unconcealment" (coming into being) and out of "concealment" (nothingness) as a thing present in accordance with a mode of "presence". 1 In adhering to the phenomenological method, Heidegger refuses to posit any conditions as lying behind this temporal mutabilitythis movement itself constituting the "being of beings". Although Foucault's project is not that of an explicit ontology as Heidegger's is, he does speak about the various transmutations in the notions and uses of language and how these are related to the constitution of our finitude (as our being) in discourse 2 . Underlying this discursive finitude, Foucault hypothesizes that there is a struggle of forces competing for durability - to enter into the discursive network. This emergence into the discursive network, for Foucault, is the "event" of being, the emergence of a specific relation of forces, in its least complex and most durable form, resulting from a battle of forces.

For both Heidegger and Foucault, this temporal movement of a transient event becomes artificially preserved as a "being"-an entity, thing, substance, object, essence, hypokeimenon, subjectum-persisting through-out its temporality as a superficially structured a-temporality-claiming to be an "eternity" (at least for. the time being), differentiated and autonomous from its temporal existence. 3 This "preservation" is accomplished in relation to

1 According to Reiner Schürmann's excellent writings on Heidegger, being for Heidegger can be thus described in three different ways: "presencing" as the emergence into existence doubled with "absencing" as perishing out of existence, "presence" or "beingness" as the mode according to which the presencing is accomplished to linger for a while before absencing, and the entity that is "present" in accordance with the mode of presencing. Heidegger charges metaphysics with looking only to "presence" - the parousia (presence) of an idea for the phusis (emergence) of an ousia (substance) in Aristotle - as the ground of being, posited as an absolute. See Schürmann's book on Heidegger titled Heidegger on Being And Acting.

2 By "discourse" or "discursivity", Foucault means the network or configurations of how and what we know and how we communicate this knowledge, constituting our own understanding of ourselves and the world, and limiting our way of existing in accordance with this understanding. On the surface level, such a configuration of knowledge seems to be absolute, thus gripping us in its hold as a "regime of truth". But hidden under its apparent rigidity, there lies its mutability due to the multiplicity and temporality of disparate elements constituting the claimed universality and eternity of any knowledge.

3 The English translation of Heidegger's uses of the terms Sein as the process of "being" ("is") as a verb and Seiendes as the entity that "is" - "being" as a 
language which constitutes our knowledge of being in terms of objects and concepts by the act of naming "that-which-cannot-be-named".4 But once thus named, the mutability of the event continues unbeknownst to us in accordance with the transformations of language covering over its temporality. This tendency of language - the crystallization or solidification of being as something durable - continues towards its totalizing self-closure wherein that which is posited as being present becomes preserved as an absolute mode of presence, resulting in the reign of a discursive truth regime, the historical rule of an epistemei for Foucault, an epoch of being for Heidegger.

Before preceding, I would like to clarify my position and intention. While I am aware of the fundamental differences between the philosophy of Heidegger as an ontology of being and that of Foucault as an archaeology of knowledge and genealogy of power undertaken for the sake of cultural critique, as a part of a more extensive project, I am concentrating here on the interesting parallels in the conclusions reached by the two philosophies which make them comparable. I see interesting converging points especially in their analyses of language as a mutability mutating through time. For Heidegger this proves to be an ontological history of being "unconcealing" itself from the indeterminate originariness of temporality into various determinate modes through history, while for Foucault, this proves to be a history of "truth" and knowledge-power formations constituting what we ourselves are and our knowledge of what we are with various techniques of power. The main difference would be the fact that while Heidegger is interested in formulating an ontology, Foucault is interested in looking at the limiting configurations which constitute what and how we are for the possibility of mutating beyond them. But while Heidegger's project is that of an ontology, since it looks at being as this very movement of temporal mutations-called "unconcealment" or "presencing"-one could say that he is looking at the same phenomena Foucault sees in his "critique". And for both, this proves to be a phenomenological destruction of metaphysical posits as being transient and contingently depending on their a priori temporality and irreducible plurality contrary to their claims. Therefore, while this paper is mainly about the similarities between the thoughts of

noun - can be confusing. While some scholars have translated the prior sense of "being" as "Being" with a capital " $B$ " in contrast to "being" with a small " $b$ " as the entity, I feel that the use of a capital " $B$ " in English, makes Sein sound like some absolute entity or metaphysical principle designated by a pronoun, ruling other "beings". Instead, in this paper, for the most part, I will use "being" to translate Sein as the process of be-ing, and "entity" or "thing" to translate Seiendes as that which "is".

4 For both thinkers, naming would be an attempt at re-presenting that which is no longer present beyond its temporal "event" with a sign. The signifying name serves to retain the phenomenon beyond its temporality with an artificiality replacing the original which is no longer present. Moreover, it also serves to unify that which in its self may be a dispersed multiplicity of phenomena and phenomenal events into an individuality which can be conceptualized in accordance with a universal category as a particular example. However, the substantiating name serves to re-present the event only insofar as it distorts it as such beyond its original temporality and plurality. The event is brought to us only through mediation distorting it into a thing. Insofar as an immediate re-presentation of an event is impossible, it cannot be "named". 
Heidegger and Foucault on language and being, this does not mean that I am unaware of their basic differences in purpose.

Let us first examine Heidegger's notion of being. For Heidegger, the primordiality of that which is, lies in its momentary comging-to-be and perishing ("presencing" and "absencing")- the two-fold movement of an ongoing coming into being out of the veil of nothingness, behind which nothing is present and beyond which nothing is given in its totality. This presencing, as a revealing of a thing emerging into being, always requires a partial concealment which serves as an ordering limit to determine the revealed thing as that which endures while also concealing the transitoriness of its temporal endurance finitizing it. This presencing in time within the determining bounds of concealment, the temporal movement of partial disclosure in a momentary and transient coming-to-presence is the meaning of what the Greeks called "aletheia", commonly translated as "truth". And this movement of presencing out of concealment into unconcealment, is the being of entities.

Since being, as this on-going process, is not a durable thing-in-itself lasting through its transitoriness, it can only be spoken through metaphor in language. However, this proves to be an inevitable distortion of being, the movement of unconverING, into a thing, designated with a name as that which was uncoverED.5 And the choice of one group of metaphors over another is important in that the interpretation of the meaning of being is produced through that metaphorical insistance. In this way, for Heidegger, language necessarily accompanies being in its realization, crystallizing it into an enduring form as the entity appearing in its presencing. But for Foucault, this seeming arbitrariness of one set of phenomena enduring as an entity instead of another set of phenomena, points to a "struggle for power" between conflicting forces. From out of such a conflict, the stronger forces are able to erupt into being as an enduring set at the expense of weaker sets of forces. Thus one could perhaps say that what Heidegger calls "being" is equivalent to what for Foucault is the event of forces erapting into being in accordance with discursive knowledge formations. For Foucault, this is the movement of an hypothetical eruption of forces in conflict, from out of which an economy of the least complex and most durable form of forces emerges.

For Foucault, that which is, is this non-corporeal effect produced by an intangible and inaccessible battle of forces colliding, mingling, seperating, and "forming a succession of links".6 From the initially local circumstances of events and forces, the "least complex local morphology" compatible with the circumstances is produced. However these forms, made up of momentary events of conflicting forces relating to one another, are unstable. To paraphrase what Lyotard says, they are nothing but "islands of determinism...in a constant flux due to changing circumstances." 7 And language is one such form. Thus for Foucault, this eruptive entry of struggling forces, competing for durability, uniformity, simplicity, economy,

5 Martin Heidegger, "What Are Poets For?" in Poetry, Language, And Thought, p. 132; trs. by Albert Hofstadter, NY: Harper \& Row, 1971 .

Dichel Foucault, "Theatrum Philosophicum" in Language, Counter-Memory, Practice, p. 173; ed. \& trs. (with Sherry Simon) by Donald F. Bouchard, Ithaca, NY: Cornell University Press, 1977.

7 Jean-Francois Lyotard, The Postmodern Condition, p. 59; trs. by Geoff Bennington \& Brian Massumi, Minneapolis: University of Minnesota Press, $1975,1984$. 
etc., making its emergence into language is "truth or being" revealed at the very exteriority of what we know. ${ }^{8}$

Therefore, for both Heidegger and Foucault, whether it is from a conflict of forces or from concealment, being entails a process -the very emergence of something which can be taken as a durable thing made known and recognizable through language naming it - an emerging which according to Heidegger, the Greeks called "poiesis". 9 However, since this movement in itself is not the permanence of a thing taken as an object, it is in need of an atemporal preservation in order to be taken as that which endures throughout its temporal presencing-a "thing".10 That is why Heidegger says that the essence of a thing lies in its temporal "gathering" (legein, verb of logos) to make it "stay" through time.11 And language is one way in which this gathering is accomplished. Thus "poesy" for Heidegger is the original essential form of language- the happening in which beings are linguistically disclosed.

Being as poiesis and logos, also called the "saying" of being in Heidegger's later writings after Being And Time, is what accomplishes this unconcealment of an enduring being through difference. Through differentiation from the surrounding flux of becoming, the entity is made to stand as a particular thing preserved from out of its event of presencing. This is what Heidegger calls "apartness". In this apartness, the entity becomes limited and differentiated in "safety" from the rest of the flux of presencing. 12 And through this cutting of a "trace" to determine it and differentiate it from others- the "(de)sign" of language as being's sayingdefinition or meaning is given to language within an "open clearing" (defined by borders) where things can appear, persist, and depart.13 According to this design unfolded into the "structure of manifold showing", we receive the measure of entities present as well as those absent through their apartness. 14

8 Foucault, "Nietzsche, Genealogy, History" in Language, Counter-Memory, Practice, p. 146 \& 147.

9 Heidegger, "The Question Concerning Technology" in The Question Concerning Technology And Other Essays, p. 10 \& 12; trs. by William Lovitt, NY: Harper \& Row, 1977.

10 Heidegger, "Origin of the Work of Art" in Basic Writings, p. 131 \& 168; ed. by David Farrell Krell, SF: Harper \& Row, 1977.

11 Reiner Schürmann, Heidegger On Being And Acting, p. 211; trs. by Christine-Marie Gross (in collaboration with the author), Bloomington, IN: Indiana University Press, 1987, 1990. Another thinker of "post-modernity", Lyotard also tells us that since there "should" be only one proper denomination of that which one talks about to differentiate it from others, the Greek verb "legein"-originally understood in ancient Greece as the gathering of what was unconcealed by talking about it as some thing-thus became transformed to mean "to name something". See Lyotard's Differend, P. 35-7; trs. by Georges Van Den Abbeele, Minneapolis: University of Minnesota Press, 1983, 1988.

12 Heidegger, "The Turning" in The Question Concerning Technology And Other Essays, p. 45; "The Way to Language" in On The Way fo Language, p. 115, trs. by Peter D. Hertz, SF: Harper Collins, 1959, 1971; "Origin of The Work of Art", p. 185.

13 Heidegger, "The Way to Language", p. 127.

14 Heidegger, "The Way to Language", p. 131; "The Age of the World Picture" in The Question Concerning Technology And Other Essays, p. 145. 
In Foucault, language is related to the eventful conflict of forces from out of which it emerges to determine the existence of an entity with limits. From out of the pre-phenomenal nothingness, the "flashing" of this event lights up to determine the clarity of its own manifestation in accordance with the limit provided by the surrouding nothingness. Simultaneously, as in Heidegger, the existence of that which was shown in the light comes to be retained in language through the designation of its limiting difference from its surroundings. 15 Through the designating constitution of a limit at the periphery of the flash, meaning is allowed to be affirmed in the emergence of what Foucault calls "statement". Through this affirmation, the mode of the event is determined and defined for our understanding as an identity different from that which lies outside of it. 16 Thus while it defines the event, the statement simultaneously provides existential meaning to a group of signs to function as language.17 And from within such a space of delimitation, a whole network of statements can emerge to provide a relation of signs with meaning so they can make sense within the context of the network-what Foucault calls "discourse".18 In this way, by the functioning of signs as a repeatable materiality within discourse, the event becomes neutralized into a "thing-concept" determined according to rules. 19

This material existence of signs is viewed by both Heidegger and Foucault as being necessary for the determinate materialization of the "statement" or the "saying" of unconcealment, into language according to linguistic rules. For Foucault, the statement can only be received by our understanding through its determinate materialization, the spatio-temporal individuality of a group of signs controlling it and providing it with substance - in turn, the signs become provided with existential meaning. 20 And for Heidegger as well, logos can only be understood through the signs of sounds and mental experiences signifying things. 21 Thus, according to Foucault, the order upon which our understanding depends, can only exist in this linguistic "grid" of signs within which the contents of statements are constituted.22 And from within this discursive network, "constants" can emerge to neutralize the temporal event so that the statement can be repeatedly recognized in a general form.23

Therefore, for both thinkers, the power to preserve the moment of being into its repeatability is related to language-in the act of naming through the word. As the vocal and written sign that names, Foucault says that the word (a noun by nature) captures an uncovered thing out of its discoveredness by designating its presentation in a representation. 24 Only by virtue of such an act, can the movement of uncoverING for Heidegger, show itself as the uncoverED, a thing. Thus Heidegger says that the word gives being to the thing to establish it as a thing by way of its name. ${ }^{25}$ The naming word

15 Foucault, "A Preface to Transgression" in Language, Counter-Memory, Practice, p. 35-6.

16 Foucault, The Order of Things, p. 119, NY: Random House, 1970.

17 Foucault, Archaeology Of Knowledge, p. 111-2; trs. by A.M. Sheridan Smith, NY: Pantheon Books, 1972.

18 Foucault, Archaeology of Knowledge, p. 99.

19 Foucault, Archaeology of Knowledge, p. 85-8 \& 107-9.

20 Foucault, Archaeology of Knowledge, p. 100-1.

21 Heidegger, "The Nature of Language" in On the Way to Language, p. 97.

22 Foucault, The Order of Things, p. xx; Archaeology of Knowledge, p. 114.

23 Foucault, Archaeology of Knowledge, p. 101.

24 Foucault, The Order of Things, p. 97.

25 Heidegger, "The Nature of Language", p. 62-3 \& 86-7. 
"holds, relates, and keeps the thing as thing" 26, making it "persist in (its) presence". 27 According to Foucault, once the event becomes preserved through the naming noun, it loses its momentary intensity in favor of the rigidity making it more or less permanent.28 The word unifies the diversity and discontinuous elements of transient successions as an order of sequence placed upon a topological space where common names can be related to each other.29 And only through this function of the naming noun, can a group of signs become a statement to hold the possibility of recurring within a discursive network.30

Thus, for Foucault, once the event becomes specified with a name to be differentiated from others, it simultaneously comes to be controlled by a set of discursive truth-rules within which it is placed. This is made possible by the circulation of words as object-concepts and their relations with one another, setting up rules as a "space of co-existence", a "field of statements", according to which words, statements, concepts, objects, etc., become subjected. 31 Thus as a complex network which governs the regularity of statements by delimiting a field of objects, discourse determines a perspective with norms fixed in accordance with it.32 For the Heidegger of Being And Time, this discursive network called "Rede" is the mode of intelligibility underlying any interpretation or assertion ${ }^{33}$, the "existentialontological "foundation of language. ${ }^{34}$ It is the totality of significations expressing the intelligibility of what Heidegger calls our "being-in-theworld"- an expression which is constituted through language as its worldly being. 35 Only in accordance with this network providing definite and certain limits 36 , can we structure and articulate our existential condition of our wordly being and our relating with other entities.

Both Heidegger and Foucault speak of this crystallization of mutability through its assimilation into a network of discursive rules establishing itself as absolute. For Foucault, with the establishment of rules according to which elements are subjected, a "space of extremity" comes to identify itself as a united discourse different from other discourses. ${ }^{37}$ And within this unity, the event becomes assimilated into a concept holding the illusion that it refers to a single object.38 Moreover, Heidegger would add that once a discursive topic becomes spoken in a "pronouncement" (Ausspruch), it becomes used as a standard measure for any further discourse concerning the topic, to determine its originary unconcealment according to the mere "appropriateness of facts". 39 But while this network of names as a discursive

26 Heidegger, "The Nature of Language", p. 82.

27 Heidegger, "The Nature of Language", p. 95; also "Words" in On the Way to Language, p. 146 and "The Turning", p. 46.

28 Foucault, "A Preface to Transgression", p. 35.

29 Foucault, The Order of Things, p. 114-6.

30 Foucault, Archaeology of Knowledge, p. 89.

31 Foucault, Archneology of Knowledge, p. 38, 121, \& 147.

32 Foucault, "History of Systems of Thought" in Language, Counter-Memory, Practice, p. 199; \& Archaeology of Knowledge, p. 64-5 \& 116.

33 Heidegger, Being And Time, p. 204 (English); trs. by John Macquarrie \& Edward Robinson, NY: Harper \& Row, 1962.

34 Heidegger, Being And Time, p. 203.

35 Heidegger, Being And Time, p. 206.

36 Heidegger, Being And Time, p. 205.

37 Foucault, Archaeology of Knowledge, p. 57.

38 Foucault, Archneology of Knowledge, p. 31 \& 180-2.

39 Heidegger, Being And Time, p. 212. 
unity can claim autonomy, as Foucault says, it is never absolutely certain and is always limited by the silencing border determining it against everything that it is not 40 , preventing the name from ever verifying the facticity of the event it claims to hold, resulting in an intelligibility which prohibits the immediacy of its claimed origin-a condition which either becomes ignored or displaced into the future by the positing of a telos. According to Foucault, within a period of time, such discursive borders can come to constitute a "corpus of knowledge" or episteme as a total set of discursive regularities, practices, and relations uniting a given period, presupposing the same fundamental perspective. 1 This notion is comparable to Heidegger's notion of an epoch of being.

In spite of their repeatability within a period of time, the material contingency of signs, while making statements repeatable, also makes their meaning and identity modifiable, even if unintentionally. Since the discursive rules themselves are anonymous and historically determined in time and space for the definition of a given social, economic, geographical, linguistic area, Foucault says that a discourse is always finite and limited.42 But since it can never simultaneously occupy all the possibilities opened up to it, it is necessarilly incomplete, and its limiting rules are fluid. Because of this perpetual incompletion, a discourse can influence the dispersion of its inner-elements to move beyond the initial domain into new systems governed by distinct rules or to influence the birth of a new discourse. 43

In Foucault's notion of the fluid but limiting discourse, one can find converging points with Heidegger's notion of the unconcealment of being through an openess of discursivity. For Heidegger, we live within this openess of on-going unconcealment out of concealment, manifested through language defining limits to our world by seperating us from the unknown. Only in accordance with this space, can we speak and think.44 For both thinkers, truth-its intelligibility - depends on this unintelligible limiting movement finitizing human thought captured in language. In this way, Heidegger's phrase of "being-in-the-world" is related to his phrase "to-be-ina-language" - which is also "being-in-a-discourse" for both thinkers: to live within a limited but flexible openess of meaning determined by the prelinguistic. 45 For Foucault, this pre-linguistic event is what serves as the secret origin of a discourse, withdrawing its presence as an anonymous lack operating on the discursive field within which we act according to its operation.46 Therefore, in relation to the transformations of language through time, as being itself changes through its on-going unconcealment (for Heidegger) and discursive knowledge goes through tranformations (for Foucault), the defining limits of our own being continue to change as well.

The susceptibility of signs to environmental differences in time, place, and matter, enables what Foucault calls the "statement" to go through transformations irreducible to any grammatical or logical form. 47 And for Heidegger, as words become "vacuously" circulated through time and space,

40 Foucault, "Father's No" in Language, Counter-Memory, Practice, p. 79.

41 Foucault, Archaeology of Knowledge, p. 33 \& 191-2.

42 Foucault, Archaeology of Knowledge, p. 74 \& 117.

43 Foucault, Archaeology of Knowledge, p. 67 \& 173.

44 Heidegger, "The Way to Language", p. 112 \& 128-9.

45 Compare Heidegger, "A Dialogue on Language" in On the Way to Language, p. 23; "The Nature of Language", p. 79; and "Introduction to Being And Time" in Basic Writings; with Foucault's Archaeology of Knowledge, p. 76.

46 Foucault, Archaeology of Knowledge, p. 25 \& 63.

47 Foucault, Archaeology of Knowledge, p. 102. 
via "gossiping" and "passing the word along" ("idle talk"), distributing the intended meaning of an event, their relation to being becomes forgotten and they become further displaced from their actual presencing through various interpretations-each claiming to refer to a determinate fact or a supposed ideality for self-justification as a pronouncement, while continuing to point to the lack of this missing event no longer present. Thus as the standard measure, the pronouncement comes to dominate being in a plurality of different versions according to Heidegger 48 , and the event becomes articulated in multiple ways to give birth to different meanings according to Foucault.49 Therefore, the guarrantee of an inter-subjective consensus between the different meanings attached to an identical word, representing something of which its presence is lacking, becomes lost.

While the origin of an event no longer present for us becomes represented within discursive domains, there also exist for Foucault, discursive borders separating us from the presence of not merely singular events but of a whole epistemic horizon. Such a border which historically limits us in time to differentiate our presence from previous discourses we can no longer be a part of, is called the "archive" (arche) by Foucault. 50 The willful positing of the presence of an origin which we can no longer experience but would justify a given discourse, brings us closer to our archive temporally finitizing us. This eventually makes our temporal contingency explicit, and when we accept it along with the contingency of the posited origin, a dispersion of its meaning is set off from within the discourse to de-stabilize the discourse-altering the course of our delimitation towards new possibilities in the future. Thus discursive borders are finitizing but fluid and changeable, always in a state of tension and instability. 51 While our reality is established according to these discursive rules, the grounding of the rules, irreducible to any absolute system, changes through history, changing our being along with the discursivities determining our being.52 thus the lack of a stable ground which the discourse attempts to conceal with an absolutizing but superficial claim, is always accompanied by the possibility for its explicitation which would de-stabilize the superficial hold.

To counter its de-stabilizing pull, a discourse may sink to a conservative position, perpetually securing preservation for the time being, to artificially cover up its inner-instability by positing a foundation greater than itself-a main characteristic of Western metaphysical thinking which seeks to master the chaotic onrush of unconcealment by discovering something within it and grasping it as what is permanent. A source of contention for Heidegger, this proves to be the handling of entities according to a posited mode of presence in terms of the most general substance or the knowing subject53, rather than their temporal emergence which grounds them. This is taken by Heidegger to be a reflection on the essence of being in terms of an entity claimed as the absolute suprasensory truth of the totality of what is 54 -a willful covering

48 Heidegger, Being And Time, p. 212.

49 Foucault, The Order of Things, p. 99.

50 Foucault, Archaeology of Knowledge, p. 130-1.

51 Foucault, Archaeology of Knowledge, p. 120.

52 Foucault, Archaeology of Knowledge, p. 72 \& 74; \& "History of Systems of Thought", p. 199.

53 Heidegger, "Letter on Humanism" in Basic Writings, p. 218-9.

54 Heidegger, "The Word of Nietzsche: 'God is Dead"' in The Question Concerming Technology And Other Essays, p. 54 \& 61; "The Age of the World Picture", p. 115; \& "What is Metaphysics?" in Basic Writings, p. 109. 
up of its finite and multiple foundation. 55 Similarly, metaphysics for Foucault is any discourse which aims to recover its own origin with which it can legitimately control things within its sphere, while simultaneously aiming to establish it as a universality upon which the generality of things can be established. Thus it attempts to ignore the "mad flux and anarchical difference", recognizing instead, the identity of things in an origin to be recovered.56 With the constitution of an absolute, it claims to faithfully retain the micro-event of the "now" beyond its temporal irruption into an atemporal eternity which occurred in the past but will be reclaimed in the future in a legitimate presentation.

One way metaphysics attempts to cover its gaps for the strengthening of its regime, is by positing categories in accordance with the absolute. This involves exclusionary rules for distinguishing truth from falsehood, which for Foucault, specifically entails the attachment of the effects of powerstruggles to truth.57 In order to support a discourse which can cope with chance-events and evade material contingency, language becomes conceived as a plenitude of categories for resolving inner-discontinuities and subjecting inner-differences with rules of exclusion (division and rejection). 58 Claiming to be a priori, categories come to establish an order upon which resemblances are legitimated and conceptual objectivity is guarranteed.59 Based on this authority of categories, a space is created within which what in Heidegger would correspond to truth as "correctness" (Richtigkeit) according to a truth-falsity dichotomy, is allowed to operate.60

Through this utilizing of the metaphysical language of categories-the positing of absolutes mediated by categories while exluding the unsubsumable as non-existent-a discursive regime desperately struggles against its oblivion. Foucault mentions how the temporal emergence of a discourse becomes metaphysically bent for the purpose of mastering its history with a suprahistorical perspective.61 Alluding to the same Greek notion of truth Heidegger speaks of (aletheia as unconcealement), Foucault explains how as forms of knowledge mutate through history, the truth of a discursive event "hardens" into what was said in the discourse, a form posited as unalterably persisting through the fluctuating appearance.62 From out of the discursive field where forces struggle against each other for the emergence of a durable relation holding them together and appearing to last-the "hardening" of truth-knowledge as we know it in Foucault's analysis, is born to lay claim to primacy while it itself becomes subordinated to the discursive network for the purpose of legitimating the truth-claim

55Heidegger, "Introduction to Being And Time", p. 81.

56 Foucault, "Theatrum Philosophicum", p. 182; \& "Nietzsche, Genealogy, History", p. 143.

57 Foucault, "Truth And Power" in Foucaull Reader, p. 74; ed. by Paul Rabinow, NY: Pantheon Books, 1984.

58 Foucault, "What is an Author?" in Language, Counter-Memory, Practice, p. $123-4$.

59 Foucault, "Theatrum Philosophicum", p. 186.

60 Foucault, "Theatrum Philosophicum", p. 188-9. Throughout his writings Heidegger makes a distinction between "truth" as "correctness" (Richtigkeit) and "truth" as "unconcealedness" (aletheia).

61 Foucault, "Nietzsche, Genealogy, History", p. 152.

62 Foucault, Archaeology of Knowledge, p. 218; \& "Nietzsche, Genealogy, History", p. 144 \& 147. 
even if this entails "domination".63 And in Heidegger's view, everything else becomes reduced to a sameness ruled by the "truth" of concepts presupposed a priori with concealed structures, moving towards the absence of any differences.64 This has resulted in the victory of the belief in permanent and universal truths, the philosophy of "truth and identity" autonomously standing above history as "Truth" over events and difference. Thus according to Heidegger, being becomes forgotten in favor of an institutionalized consensus of truth to dominate Western thought-a form of life secretly devoted to an ideal (but unreal) world, a nothing, while ignoring the question of being itself: the mutation of being accomplished through language. And according to Foucault, the eventful emergence of a discursive configuration determining how and what we are, becomes forgotten in favor of its artificially established origin to delimit our way of being within a universalizing and eternalizing regime, disallowing any difference.

In the above analysis, I have attempted to examine what are interesting converging points within the thoughts of Heidegger and Foucault. In both Heidegger's ontology and Foucault's archaeology-genealogy, one can find a thinking concerning the temporal movement of a transient event which, whether unconcealing out of concealment as "being" or erupting-forth out of forces struggling for durable relations as a discursive knowledge-power configuration, becomes preserved as an a-temporal "thing"-a particular mode of being for Heidegger, a particular mode of knowledge in accordance with techqniques of power limiting our being for Foucault-claiming to persist throughout its temporal coming-to-be, transformations, and disappearing. For both, this proves to be an artificial preservation accomplished in relation to language constituting our knowledge and our being in terms of the universal and the eternal, the "correctness" of certainty, in the act of assigning a name to the unnameable. Because of the historical contingency of language, this tendency of obscuring the originary temporal event in favor of its crystallization as something durable through time, can continue towards a totalizing self-closure as a posited absolute for the reign of a discursive truth-regime over other discursive possibilities, and over elements placed within the discursive network, including our own being as subjected subjects. However, the fluidity and incompletion lying behind any absolute claim, also may allow for the possibility of opening up the reigning discursive network to the possibility of alternative and multiple ways of being.

63 Foucault, "History of Systems of Thought", p. 203; \& "Nietzsche, Genealogy, History", p. 150-1.

64 Heidegger, "...Poetically Man Dwells..." in Poetry, Language, And Thought, p. 218; \&c Being And Time, p. 84. 